\title{
EFEKTIVITAS METODE SPEED TEST DENGAN MENGGUNAKAN MEDIA KAHOOT! PADA PEMBELAJARAN DIMENSI TIGA
}

\author{
Malikatun Nasikhah, Afni Nurvita Dewi, Alfida Widya Yulanta, \\ Nofi Tasbihah, dan Fadhilah Rahmawati \\ Universitas Tidar, Jl. Kapten Suparman 39 Potrobangsan, Magelang Utara 56116, Jawa Tengah, Indonesia \\ Email : malikatunnasikhah@gmail.com
}

\begin{abstract}
Abstrak
Penelitian ini mempunyai tujuan untuk mengetahui efektivitas metode speed test dengan menggunakan media Kahoot! pada materi dimensi tiga. Metode dalam penelitian ini menggunakan pendekatan kuantitatif dengan jenis eksperimen semu. Sampel penelitian yaitu siswa kelas XII MIPA 4 SMA N 3 Cilacap sebagai kelas eksperimen dan kelas XII MIPA 5 SMA N 3 Cilacap sebagai kelas kontrol. Data dalam penelitian ini diperoleh dari tes akhir dan data respon siswa. Instrumen utama penelitian yaitu tes/kuis melalui apikasi Kahoot! serta angket. Analisis data efektivitas media Kahoot! dengan statistika deskriptif kuantitatif, uji normalitas, uji homogenitas, dan uji rerata dengan independent $t$ test dikarenakan kedua sampel tidak saling berkolerasi. Hasil penelitian menunjukkan bahwa terdapat perbedaan rata-rata yang signifikan antara kelas kontrol dan kelas eksperimen, rata-rata tes akhir kelas eksperimen lebih rendah dibandingkan dengan kelas kontrol, berdasarkan angket yang telah disebar mayoritas siswa kurang menyetujui keefektifan aplikasi Kahoot! sebagai media kuis interaktif.
\end{abstract}

Kata kunci: kahoot!, tes akhir, speed test.

\begin{abstract}
This research aimed to determine the effectiveness of the speed test method using Kahoot! on three dimensional material. The method of this research used a quantitative approach with a quasiexperimental type. The samples of this research were students of class XII MIPA 4 SMA N 3 Cilacap as the experimental class and class XII MIPA 5 SMA N 3 Cilacap as the control class. The data of this research were obtained from the final test and students' response datas. The instrument of the research were test/quiz through the Kahoot! as well as a questionnaire. The data analysis of this research were quantitative descriptive statistics, normality test, homogeneity test, and mean test with independent $t$ test, because the two samples did not correlated each other. The results showed that there was a significant average difference between the control class and the experimental class, the final test average for the experimental class was lower than the control class, based on the questionnaire that had been distributed, the mayority of students did not agree with the effectiveness of the Kahoot! application as an interactive quiz media.
\end{abstract}

Keywords: kahoot!, final test, speed test.

\section{Pendahuluan}

Pendidikan berperan menciptakan manusia yang berkualitas dan berpotensi, keberhasilan pelaksanaan pendidikan formal pada suatu negara tercermin dari mutu pendidikan yang tinggi [1]. Saat ini dunia Pendidikan dipengaruhi oleh pesatnya perkembangan Ilmu Pengetahuan dan teknologi (IPTEK) [2] dan IPTEK tersebut dimanfaatkan sebagai sarana untuk penyampaian materi pelajaran secara efektif.

Matematika mulai dari jenjang sekolah dasar perlu diajarkan kepada siswa supaya memiliki kemampuan untuk berpikir logis, kritis, analitis, kreatif dan sistematis serta kemampuan bekerja sama [3]. Dalam matematika salah satu 
materinya adalah geometri. Geometri merupakan ilmu pengetahuan yang mempelajari tentang ruang, bidang, garis, dan titik, serta sifat, ukuran, dan hubungan satu dengan yang lainnya. [4].

Terdapat dua faktor yang mendasari penelitian terkait inovasi pembelajaran. Pertama, sistem komputasi pada abad 21 menyebabkan pergeseran paradigma menuju meta knowledge. Kedua, meningkatnya minat belajar siswa karena masuknya era digital yang melibatkan proses kehidupan [5]. Dengan masuknya era digital dalam proses belajar mengajar dapat menentukan nilai akhir siswa secara efektif.

Dalam dunia pendidikan efektivitas pembelajaran diukur berdasarkan keberhasilan tercapainya tujuan pembelajaran dilihat dari interaksi siswa dengan siswa, atau siswa dengan guru ketika pembelajaran [6]. Efektif merupakan kata dasar dari efektivitas yang mempunyai arti suatu efek, akibat, pengaruh, atau suatu hal yang bisa mendapatkan hasil [7]. Menurut Aisyah [8] efektivitas adalah sesuatu yang menggambarkan tingkat terwujudnya suatu tujuan. Suatu ukuran tercapainya sasaran ataupun tujuan yang telah direncanakan dimana menggambarkan tingkatan target dilihat dari sisi kuantitatif, kualitatif, dan waktu disebut efektivitas [9]. Berdasarkan pengertian di atas kata efektivitas mengarah ke pencapaian sasaran ataupun tujuan. Salah satu cara meningkatkan efektivitas pembelajaran yaitu dengan memberikan unsur rangsangan agar siswa termotivasi dalam belajar, salah satunya melalui sistem evaluasi yang lebih inovatif dan kreatif yang dapat merangsang pola pikir kritis [10] .

Pengukuran kemampuan siswa dapat dipertimbangkan dengan tes berdasarkan waktu pelaksanaannya, yakni: speed test dan power test. Speed test merupakan tes yang pengerjaannya terdapat batasan waktu tertentu. Batasan waktu tersebut disesuaikan dengan tingkat soal yang ditentukan oleh guru. Struktur soal dalam speed test mempunyai kesulitan yang seragam. Peserta tes (testee) dalam speed test bisa mendapat nilai maksimal dengan menjawab semua soal yang diberikan berdasarkan rentang waktu yang cepat [11]. Kecepatan siswa ketika mengerjakan sesuatu hal dalam waktu atau periode yang ditentukan merupakan aspek yang diukur dalam tes kecepatan.

Metode speed test yang digunakan terdapat batasan waktu tertentu, dalam hal ini seperti aplikasi Kahoot! yang pengerjaannya ada durasi waktu dalam pengerjaan setiap soalnya [12]. Kahoot! merupakan pembelajaran berbasis permainan yang dianggap sebagai praktik terbaik dalam pendidikan. Penelitian dan data empiris mendukung pembelajaran permainan sebagai alat yang efektif bagi pendidik untuk digunakan di kelas karena melibatkan siswa dalam memecahkan masalah, berpikir kritis, dan meninjau pengetahuan konten [13]. Game digital adalah versi modern dari pembelajaran berbasis game yang pendidik gunakan dalam melibatkan aktivitas siswa. Dalam hal ini, pendidik dapat memanfaatkan berbagai media game yang ada. Pada awalnya Kahoot! diinisiasi dalam kerja sama antara Johan Brand, Jamie Brooker dan Morten Versvik dengan Norwegian University of Technology and Science pada Maret 2013 [14]. Dalam pembelajaran matematika, Kahoot! dapat dimanfaatkan sebagai media game online untuk melatih kecepatan siswa ketika mengerjakan soal

JARME, Volume 3, No. 1, Januari 2021, 1 - 9. 
dari guru. Kahoot! juga bisa menjadi alternatif agar siswa tidak mudah bosan dengan pembelajaran.

Berdasarkan permasalahan tersebut, penelitian ini bertujuan untuk mengetahui apakah metode speed test dengan media Kahoot! efektif digunakan sebagai kuis interaktif dalam materi dimensi tiga.

\section{Metode}

Penelitian ini dilakukan dengan pendekatan kuantitatif menggunakan jenis quasy eksperimental research. Desain eksplanasi digunakan pada pendekatan kuantitatif menggunakan objek telahan penelitian eksplanasi (explanatory research) yang dihipotesiskan dengan pengujian hubungan variabel-variabelnya [15]. Peneliti mencari perbedaan treatment (perlakuan) tertentu menggunakan jenis eksperimen semu (quasy eksperimental research). Jenis ini dipilih dengan design control berupa post test. Pada rancangan ini menggunakan tes akhir dan tidak ada tes awal. Hal ini dikarenakan peneliti hanya membandingkan hasil tes akhir dari kelas eksperimen dengan kelas kontrol. Pengaruh perlakuan dapat diketahui dengan cara kedua kelas diberikan tes akhir yang sama dan membandingkan hasilnya. Berikut rencana penelitian:

Tabel 1. Rencana Penelitian Eksperimen

\begin{tabular}{ccc}
\hline Kelas & Perlakuan & Test Akhir \\
\hline Eksperimen & $X_{1}$ & $T_{1}$ \\
Kontrol & & $T_{2}$ \\
\hline
\end{tabular}

Keterangan:

$X_{1}=$ Perlakuan menggunakan kuis berbasis aplikasi Kahoot!

$T_{1}=$ Hasil tes akhir (post test) dari kelas eksperimen

$T_{2}=$ Hasil tes akhir (post test) dari kelas kontrol

\subsection{Subjek Penelitian}

Populasi penelitian ini yaitu siswa kelas XII semester ganjil SMA N 3 Cilacap yang terdiri dari 4 kelas IPS, 5 kelas MIPA, dan 1 kelas Bahasa tahun ajaran 2020/2021. Adapun sampel yang peneliti gunakan adalah XII MIPA 5 untuk dijadikan kelas kontrol dan kelas XII MIPA 4 untuk dijadikan kelas eksperimen. Proses pemilihan subjek berdasarkan rekomendasi dari Waka Kurikulum SMA N 3 Cilacap dan dilihat dari kemampuan kedua sampel kelas yang relatif sama. Hal ini dikarenakan kedua kelas diampu oleh guru mata pelajaran matematika yang sama, sehingga antara materi dan teknik pembelajaran juga sama. Pemilihan kelas MIPA dikarenakan bahan materi penguji analisis peneliti, sesuai dengan materi yang diajarkan yaitu dimensi tiga. Penelitian ini berfokus pada analisis speed test dalam penggunaan aplikasi Kahoot!, sehingga dalam teknik pengambilan sampel peneliti membutuhkan dua sampel kelas. 


\subsection{Pengumpulan Data}

Data penelitian ini diperoleh dari data nilai tes akhir dan data respon siswa terkait keefektifan kuis berbasis aplikasi Kahoot!. Instrumen utama dalam penelitian ini yaitu soal tes/kuis melalui aplikasi Kahoot! serta angket yang peneliti sebar luaskan kepada kelas eksperimen melalui google form. Penelitian ini menggunakan tes pilihan ganda dengan materi dimensi tiga yang diujikan kepada siswa. Soal pilihan ganda dipilih karena fitur yang tersedia dalam aplikasi Kahoot! berupa pilihan ganda. Karakteristik soal yang diberikan yaitu terdiri dari soal tingkat mudah, sedang, dan sulit. Semua soal yang diberikan telah melalui proses validasi baik secara teoritis maupun empiris. Setelah tes dilaksanakan peneliti menyebarkan angket yang diberikan terdiri dari sembilan pernyataan. Hasil pembagian angket respon siswa kepada kelas eksperimen terhadap penerapan media kuis berbasis aplikasi Kahoot! digunakan untuk memperoleh data respon siswa yang ditabulasikan dan diperhitungkan perbandingan persentase respon siswa tersebut.

\subsection{Analisis Data}

Tahapan menganalisis data yaitu dengan beberapa langkah. Pertama, peneliti menggunakan SPSS 21.0 for Windows untuk mendeskripsikan data secara umum dengan melihat simpangan baku beserta rataan dari hasil tes kedua kelas. Setelah itu, peneliti melakukan uji normalitas menggunakan Shapiro-Wilk dan uji homogenitas menggunakan Levene Statistic sebagai uji prasyarat analisis. Kemudian peneliti menggunakan independent $t$ test dengan bantuan SPSS 21.0 for Windows untuk melakukan uji hipotesis penelitian.

Setelah melakukan beberapa runtutan pengujian, peneliti melakukan tabulasi data respon siswa terkait efektivitas kuis berbasis aplikasi Kahoot!. Penyajian data dalam penelitian ini berbentuk tabel dan grafik yang disesuaikan dengan data yang dibutuhkan. Penarikan kesimpulan diambil melalui perolehan data yang telah dianalisis peneliti terkait hasil keefektifan aplikasi Kahoot! dalam materi dimensi tiga tingkat SMA.

\section{Hasil dan Diskusi}

Berdasarkan rancangan penelitian untuk mengetahui efektivitas Kahoot! sebagai media kuis interaktif dalam materi dimensi tiga tingkat SMA yang telah dirumuskan maka perhitungan awal adalah melihat rataan dan simpangan baku. Berikut tabel hasil perhitungan:

Tabel 2. Hasil Perhitungan Tes Akhir

\begin{tabular}{ccccc}
\hline Kelas & N & Mean & Std. Deviation & $\begin{array}{c}\text { Std. Error } \\
\text { Mean }\end{array}$ \\
\hline Kahoot! & 32 & 50,9375 & 17,29430 & 3,05723 \\
Non-Kahoot! & 32 & 73,4375 & 24,31107 & 4,29763 \\
\hline
\end{tabular}

Berdasarkan hasil uji statistik deskriptif tes akhir, dapat diketahui gambaran umum penerapan kuis berbasis aplikasi Kahoot! serta Non-Kahoot! terhadap hasil

JARME, Volume 3, No. 1, Januari 2021, 1 - 9. 
akhir siswa. Kelas eksperimen adalah kelas yang mendapatkan perlakuan beupa kuis berbasis aplikasi Kahoot!, sedangkan istilah Non-Kahoot! digunakan untuk kelas kontrol yang tidak mendapat perlakuan. Berdasarkan hasil perhitungan dapat diketahui nilai rata-rata kuis berbasis aplikasi Kahoot! sebesar 50.9375, sedangkan Non-Kahoot! sebesar 73.4375. Adanya perbedaan skor rata-rata dari kedua kelas yaitu 22,5. Perbedaan nilai rata-rata ini menunjukan bahwa kelas eksperimen tidak lebih tinggi dibandingkan dengan kelas kontrol. Pernyataan tersebut berbanding dengan nilai rata-rata mana yang lebih tinggi dengan melihat mean pada $t$ hitung yaitu 7,538 yang menunjukan positif berarti mean dari kelas eksperimen (Kahoot!) > mean kelas kontrol (Non-Kahoot!) [16].

Ditinjau berdasarkan konsep dan prinsip, siswa mengalami tingkat kesulitan belajar yang cukup tinggi secara rata-rata pada materi dimensi tiga [17]. Rata-rata tes speed test (tes kecepatan) lebih rendah dibandingkan dengan power test [18]. Kedua pernyataan tersebut menguatkan alasan rendahnya mean kelas eksperimen dibandingkan mean kelas kontrol.

Setelah itu peneliti melakukan uji normalitas untuk mengetahui rata tidaknya penyebaran data. Adapun hipotesis untuk pengujian normalitas yaitu:

$H_{0}=$ data menyebar dengan normal

$H_{1}=$ data tidak menyebar dengan normal

Uji normalitas ini dengan taraf signifikansi $a=0.05 . H_{0}$ diterima apabila taraf signifikansi Asym.Sig. > a. Berikut ini hasil uji normalitas kuis berbasis aplikasi Kahoot!:

Tabel 3. Hasil Uji Normalitas Tes Akhir

\begin{tabular}{cccc}
\hline \multirow{2}{*}{ Kelas } & \multicolumn{3}{c}{ Shapiro-Wilk } \\
\cline { 2 - 4 } & Statistic & df & Sig. \\
\hline Eksperimen &, 948 & 32 &, 125 \\
Kontrol &, 948 & 32 &, 124 \\
\hline
\end{tabular}

Berdasarkan Tabel 3 dapat diketahui bahwa uji normalitas dengan taraf signifikan $a=0.05$ menunjukan penggunaan kuis berbasis aplikasi Kahoot! dalam materi dimensi tiga terlihat probabilitas output Shapiro-Wilk untuk kuis berbasis aplikasi Kahoot! $\left(X_{1}\right)$ adalah 0.125 dan kuis Non-Kahoot! $\left(X_{2}\right)$ adalah 0.124 . Karena nilai-nilai Asym.Sig. > a maka kedua data menyebar dengan normal.

Adapun pengujian homogenitas dilakukan guna mengetahui data nilai akhir kuis berbasis aplikasi Kahoot! dan kuis konvensional homogen atau tidak. Berikut hipotesis dalam pengujian homogenitas:

$H_{0}=$ apabila data tersebut homogen

$H_{1}=$ apabila data tersebut tidak homogen

Berikut ini hasil pengujian homogenitas kuis berbasis aplikasi Kahoot! : 
Tabel 4. Hasil Pengujian Homogenitas

\begin{tabular}{cccc}
\hline Levene Statistic & df1 & df2 & Sig. \\
\hline, 979 & 1 & 62 &, 326 \\
\hline
\end{tabular}

Berdasarkan Tabel 4 hasil pengujian homogenitas dapat diketahui bahwa kedua data tersebut homogen. Hal ini dibuktikan dengan hasil pengujian homogenitas dengan taraf 0.05 yang menunjukkan Asym.Sig. senilai 0.326 yang lebih besar dari 0.05. Hasil tersebut menunjukkan kesamaan dengan penelitian yang menyatakan nilai sig. data 0,054 >0,05, artinya varians data menggunakan model pembelajaran yang berbabis Kahoot! dan konvensional homogen [19]. Setelah uji prasyarat yaitu normalitas menunjukkan data normal dan homogenitas yang menunjukkan data homogen, maka dilakukan hipotesis dengan Independent $t$ Test.

$H_{0}=$ Tidak ada perbedaan yang signifikan tes akhir akibat kuis berbasis aplikasi Kahoot! dan konvensional.

$H_{1}=$ Adanya perbedaan yang signifikan tes akhir akibat kuis berbasis aplikasi Kahoot! dan konvensional.

Jika taraf signifikansi $a=0.05$ dengan nilai Asymp Sig $<a$ maka $H_{0}$ ditolak. Berikut hasil pengolahan data menggunakan Independent $t$ Test:

Tabel 5. Hasil Independent t Test

\begin{tabular}{|c|c|c|c|c|c|c|c|}
\hline & \multicolumn{7}{|c|}{ t-test for Equality of Means } \\
\hline & \multirow[t]{2}{*}{$t$} & \multirow[t]{2}{*}{$D f$} & \multirow[t]{2}{*}{$\begin{array}{l}\text { Sig. (2- } \\
\text { tailed) }\end{array}$} & \multirow[t]{2}{*}{$\begin{array}{c}\text { Mean } \\
\text { Difference }\end{array}$} & \multirow[t]{2}{*}{$\begin{array}{l}\text { Std. Error } \\
\text { Difference }\end{array}$} & \multicolumn{2}{|c|}{$\begin{array}{c}\text { 95\% Confidence } \\
\text { Interval of the } \\
\text { Difference }\end{array}$} \\
\hline & & & & & & Lower & Upper \\
\hline \multicolumn{8}{|l|}{ Equal variances } \\
\hline assumed & $-5,012$ & 62 & ,000 & $-22,500$ & 4,489 & $-31,474$ & $-13,526$ \\
\hline $\begin{array}{l}\text { Equal variances not } \\
\text { assumed }\end{array}$ & $-5,012$ & 61,676 & 000 & $-22,500$ & 4,489 & $-31,475$ & $-13,525$ \\
\hline
\end{tabular}

Berdasarkan Tabel 5 hasil perhitungan Independent $t$ Test untuk mengetahui keefektifan kuis berbasis aplikasi Kahoot! dan Non-Kahoot! (konvensional) terhadap nilai akhir siswa, hasil signifikan sebesar $0.000<0.05$ sehingga $H_{0}$ ditolak. Berdasarkan hasil tersebut terdapat perbedaan yang signifikan antara kuis berbasis aplikasi Kahoot! dan kuis berbasis Non-Kahoot! (konvensional) terhadap nilai akhir siswa dalam materi dimensi tiga.

Setelah pengerjaan kuis, kemudian menyebarkan angket kepada responden kelas eksperimen untuk memperoleh data respon siswa terhadap penerapan media kuis interaktif berbasis media Kahoot! [20]. Pembagian angket tersebut mempunyai tujuan untuk memperoleh data respon siswa setelah mengerjakan kuis berbasis aplikasi Kahoot!. Angket yang disebarkan terdiri dari sembilan pernyataan. Hasil pembagian angket respon siswa kepada kelas eksperimen terhadap penerapan media kuis berbasis aplikasi Kahoot! digunakan untuk memperoleh data respon siswa yang

JARME, Volume 3, No. 1, Januari 2021, 1 - 9. 
ditabulasikan dan diperhitungkan perbandingan persentasenya. Berikut gambar dari data respon siswa:

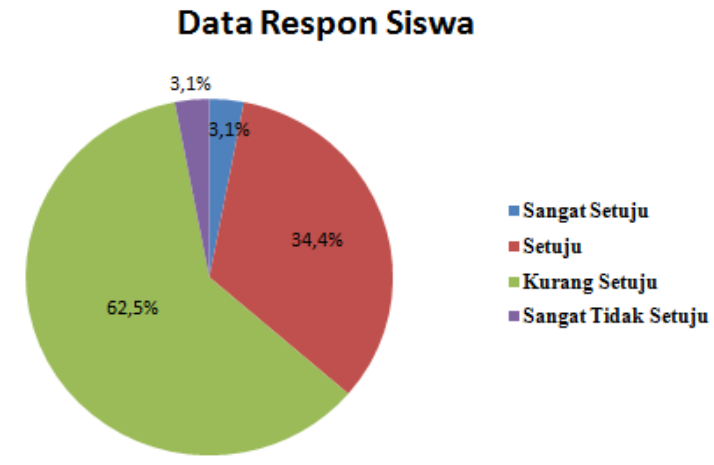

Gambar 1. Data Respon Siswa

Berdasarkan Gambar 1 data respon siswa diketahui sebanyak 3,1\% siswa kelas eksperimen sangat setuju, 34,4 \% siswa setuju, 62,5\% kurang setuju, dan 3,1\% sangat tidak setuju dengan keefektifan kuis menggunakan aplikasi Kahoot!. Hal ini dapat diketahui bahwa siswa dominan kurang setuju terkait efektivitas kuis berbasis aplikasi Kahoot!. Hasil dari peneliti berbanding dengan pernyataan penggunaan aplikasi Kahoot! terbukti lebih efektif dalam proses belajar [21]. Serta aplikasi Kahoot! sebagai alat evaluasi sangat efektif ditinjau dari indikator motivasi dan atensi peserta didik [10]. Pada pembelajaran menggunakan aplikasi Kahoot! terdapat peningkatan minat belajar siswa dilihat dari aktivitas belajar dan wawancara [22]. Hal tersebut menunjukkan adanya perbedaan hasil penelitian dengan penelitian yang peneliti lakukan.

Metode kuis berbasis aplikasi Kahoot! dalam materi dimensi tiga tingkat SMA kurang efektif. Hal ini terbukti dari hipotesis awal penelitian, yang menunjukan bahwa nilai rata-rata kelas eksperimen lebih rendah daripada kelas kontrol. Hal ini berbanding dengan Sari [23] yang menyatakan lebih tingginya nilai rata-rata kelas eksperimen (dikenai metode kuis interaktif/Kahoot!) dibandingkan dengan kelas kontrol (dikenai konvensional). Serta penelitian yang menyatakan bahwa sangat efektifnya kuis interaktif berupa Kahoot!, namun pengoptimalan pemanfaatan teknologi masih minim dan masih banyak kendala dalam penerapannya [24]. Perbedaan hasil penelitian ini diakibatkan beberapa faktor, diantaranya penelitian yang dilakukan peneliti tidak secara langsung (penelitian jarak jauh), kelas eksperimen baru pertama kali menggunakan aplikasi Kahoot!, serta banyaknya siswa yang terkendala sinyal selama proses pengerjaan.

\section{Simpulan}

Simpulan dari penelitian ini adalah ada perbedaan yang signifikan antara kelas kontrol dan kelas eksperimen, rata-rata tes akhir kelas eksperimen lebih rendah dibandingkan dengan rata-rata tes akhir dari kelas kontrol. Berdasarkan angket yang disebar, 
mayoritas siswa kurang menyetujui keefektifan aplikasi Kahoot! sebagai media kuis interaktif.

Penelitian ini masih memiliki keterbatasan yaitu kurang matangnya persiapan sampel penelitian dalam melaksanakan kuis berbasis aplikasi Kahoot! serta kendala jaringan internet untuk mengakses aplikasi Kahoot!. Dari hasil penelitian yang diperoleh, kami menyarankan penelitian selanjutnya lebih mengoptimalkan fasilitas, terutama jaringan internet, sehingga kuis berbasis aplikasi Kahoot! dapat terealisasikan dengan baik. Fasilitas yang optimal diharapkan mampu menjadikan pengerjaan siswa secara sungguh-sungguh, tanpa mengkhawatirkan kendala sinyal, sehingga akan memperoleh hasil yang maksimal.

\section{Ucapan Terimaksih}

Terimakasih kepada pihak yang mendukung kelancaran penelitian ini terutama kepala sekolah, guru kelas, serta guru matematika SMA Negeri 3 Cilacap yang telah memberikan ijin. Selain itu, terimakasih kepada siswa kelas XII MIPA 4 dan XII MIPA 5 yang telah berpartisipasi.

\section{Referensi}

[1] Susanto H, Rinaldi A \& Novalia 2015 Analisis Validitas Reabilitas Tingkat Kesukaran dan Daya Beda pada Butir Soal Ujian Akhir Semester Ganjil Mata Pelajaran Matematika Al-Jabar: Jurnal Pendidikan Matematka 6(2) 203-217 doi: 10.18907/jjsre.37.3_343_4

[2] Jamun Y M 2018 Dampak Teknologi terhadap Pendidikan Jurnal Pendidikan dan Kebudayaan Missio 10(1) 48-52

[3] Rahmawati F \& Sugiman 2015 Komparasi Kemampuan Penalaran Siswa Kelas VIII antara Model Pembelajaran Think Talk Write ( TTW ) dan Two StayTwo Stray ( TS-TS ) Prosiding Seminar Nasional Matematika dan Pendidikan Matematika 533-538

[4] Sardjana A 2008 Materi Pokok Geometri Ruang (Jakarta: Universitas Terbuka)

[5] Kereluik K, Mishra P, Fahnoe C \& Terry L 2013 What Knowledge Is of Most Worth: Teacher Knowledge for 21st Century Learning Journal of Digital Learning in Theacher Education 29(4) 127-140 doi: 10.1080/21532974.2013.10784716

[6] Rohmawati A 2015 Efektivitas Pembelajaran Jurnal Pendidikan Usia Dini 9( 1) $15-32$

[7] KBBI 2020 Kamus Besar Bahasa Indonesia (KBBI) [Online] Available at: http://kbbi.web.id/efektifitas [Diakses 26 Oktober 2020]

[8] Asiah S 2016 Efektivitas Kinerja Guru TADBIR: Jurnal Managemen Pendidikan Islam 4(2) 1-11

[9] Nasution M I P 2016 Strategi Pembelajaran Efektif Berbasis Mobile Learning pada Sekolah Dasar IQRA': Jurnal Perpustakaan dan Informasi 10(01) 1-14

[10] Daryanes F \& Ririen D 2020 Efektivitas Penggunaan Aplikasi Kahoot sebagai Alat Evaluasi pada Mahasiswa Journal of Natural Science and Integration 3(2) 172-186 doi: 10.24014 /jnsi.v3i2.9283

[11] Mahendra I W E, Jayantika I G A N T \& Sulistyani N W R 2019 HOTS-Speed Test untuk Meningkatkan Kemampuan Penalaran Analisis Peserta didik AKSIOMA: Jurnal Matematika dan Pndidikan Matematika 10(1) 93-101 doi: 
10.26877/aks.v10i1.3772

[12] Lisnani \& Emmanuel G 2020 Analisis Penggunaan Aplikasi KAHOOT dalam Pembelajaran IPA JIPI (Jurnal IPA Pembelajaran IPA) 4(2) 155-167 doi: 10.24815/jipi.v4i2.16018

[13] Dellos R 2015 Kahoot! A Digital Game Resource for Learning Internatonal Journal of Intructional Technology and Disance Learning 12(4) 49-52 doi: 10.13021/g8060p

[14] Rofiyarti F \& Sari A Y 2017 TIK untuk AUD: Penggunaan Platform 'Kahoot!' dalam Menumbuhkan Jiwa Kompetitif dan Kolaboratif Anak Pedagoi: Jurnal Anak Usia Dini dan Pendidikan Anak Usia Dini 3(3b) 164-172

[15] Mulyadi M 2011 Penelitian Kuantitatif Dan Kualitatif Serta Pemikiran Dasar Menggabungkannya Jurnal Studi Komumikasi dan Media 15(1) 127-138 doi: $10.31445 /$ jskm.2011.150106

[16] Mafruhah S, Sulistiani I R \& Mustafida F 2019 Pengaruh Penggunaan Media Pembelajaran Interaktif Berbasis Aplikasi (Kahoot) Terhadap Hasil Belajar Siswa Kelas XI di SMAI Al-Maarif Singosari Malang VICRATINA: Jurnal Pendidikan Islam 4(7) 23-29

[17] Syahrir S, Kusnadin K \& Nurhayati N 2013 Analisis Kesulitan Pemahaman Konsep dan Prinsip Materi Pokok Dimensi Tiga Siswa Kelas Xi SMK Keperawatan Yahya Bima Prisma Sains: Jurnal Pengkajian Ilmu dan Pembelajaran Matematika dan IPA IKIP Mataram 1(1) 88-102 doi: 10.33394/j-ps.v1i1.522

[18] Sari R 2012 Perbandingan Motivasi Belajar Siswa Antara yang Memperoleh Tes Kecepatan (Speed Test) dengan Tes Kemampuan (Power Test) pada Bidang Studi Matematika (Thesis: Institut Agama Islam Negeri (IAIN) Syekh Nurjati)

[19] Maulidah E, Syaf A H, Rachmawati T K \& Sugilar H 2020 Berpikir kritis matematis dengan Kahoot Jurnal Analisa 6(1) 19-27 doi: 10.15575/ja.v6i1.8516

[20] Ningrum G D K 2018 Studi Penerapan Media Kuis Interaktif Berbasis Game Edukasi Kahoot! Terhadap Hasil Belajar Mahasiswa VOX EDUKASI: Jurnal Ilmiah dan Ilmu Pendidikan 9(1) 22-27 doi: 10.31932/ve.v9i1.32

[21] Irwan I, Luthfi Z F \& Waldi A 2019 Efektivitas Penggunaan Kahoot! untuk Meningkatkan Hasil Belajar Siswa [Effectiveness of Using Kahoot! to Improve Student Learning Outcomes] PEDAGOGIA: Jurnal Pendidikan 8(1) 95-104 doi: 10.21070/pedagogia.v8i1.1866

[22] Irawati M 2018 Profil Minat dan Hasil Belajar Siswa dalam Pembelajaran Matematika Kelas VIII SMP Negeri 5 Yogyakarta pada Pokok Bahasan Penyajian Data Dengan Menggunakan Aplikasi Kahoot (Thesis: Universitas Sanata Dharma)

[23] Sari D P, Putra R W Y \& Syazali M 2018 Pengaruh Metode Kuis Interaktif terhadap Kemampuan Pemecahan Masalah Matematis Mata Kuliah Trigonometri Jurnal Pendidikan Matematika 12(2) 63-72

[24] Centauri B 2019 Efektivitas Kahoot! sebagai Media Pembelajaran Kuis Interaktif di SDN 7 Bukit Tunggal Prosiding Seminar Nasional Pendidikan MIPA dan Teknologi (SNPMT II) 124-133 